\title{
Aleksandra Koszarek-Cyra*
}

\section{USŁUGI EKOLOGICZNE JAKO ELEMENT OCENY OPŁACALNOŚCI INWESTYCJI}

Z a r y s tr e ś c i: Przedmiotem rozważań zawartych w artykule jest istota koncepcji waloryzacji usług ekosystemów. Podjęto próbę zarówno scharakteryzowania tych usług, jak również wskazania istotności oceny ich wartości jako elementu inwestycyjnego procesu decyzyjnego dotyczącego opłacalności. Przytoczono również przykładowe metody oceny wartości usług ekosystemowym z jednoczesnym wskazaniem trudności które towarzyszą temu procesowi.

S ło w a k 1 u c z o w e: usługi ekosystemów, ocena wartości usług ekosystemowych, koszty środowiskowe

K 1 a s y fik a c j J E L: L 21; Q51

\section{WSTĘP}

Wiek XX był wiekiem zmian, zarówno w kontekście społeczno-politycznym jak również $\mathrm{w}$ aspekcie gospodarczym. W obrębie kilku pokoleń nastąpił nie tylko gwałtowny wzrost liczby ludności (ok. 700\% w stosunku do początków wieku XIX) ale również całkowita przemiana życia społecznego, spowodowana przede wszystkim możliwościami jakie przyniósł rozwój przemysłu, w szczególności elektronicznego i idącej za tym globalizacji. Dzięki łatwiejszej drodze pozyskiwania i wymiany informacji, a także transferu wiedzy na poziomie globalnym zaczęto zwracać uwagę również na zagadnienia dotychczas pomijane celowo lub niezauważane, do których należały $\mathrm{m}$. in. problemy ochrony środowiska naturalnego.

\footnotetext{
Adres do korespondencji: Aleksandra Koszarek-Cyra, Politechnika Częstochowska, Wydział Zarządzania, ul. Armii Krajowej 19b, 42-200 Częstochowa, e-mail: ola.cyra@gmail.com;
} 
Można stwierdzić, że to dzięki wzrostowi wiedzy i społecznej świadomości środowiskowej nastąpiły zmiany również w funkcjonowaniu organizacji, w kierunku bardziej przyjaznych środowisku, czego efektem było stworzenie koncepcji zrównoważonego rozwoju i jej implementacja do życia społeczno- gospodarczego. Obecnie można mówić o rozwoju tzw. kultury i etyki ekologicznej, które zakładają użytkowanie przyrody z poszanowaniem jej praw. [Poskrobko B. 2007, s. 59]. Jednocześnie coraz częściej wskazuje się na znaczenie ochrony kapitału naturalnego nie tylko w wymiarze etycznym- jako elementu, który należy zachować dla przyszłych pokoleń, ale również ekonomicznym w o wiele szerszym zakresie niż było to czynione do tej pory. Coraz częściej utowarowiane są zasoby, które wcześniej uważano za bezwartościowe (np. z powodu braku technologii pozwalających na opłacalną ich eksploatacje), jak również te które stały się deficytowe w wyniku degradacji środowiska czy wzrostu liczby ludności takie jak na przykład woda pitna. [Górnicki K. 2012, s. 271-297]. W wyniku rozwoju tzw. ekonomii ekologicznej zaczęto podejmować próby oceny wartości poszczególnych części środowiska, nie tylko pod względem zasobów dostarczanych do procesów produkcji i konsumpcji ale również jako elementy czy struktury świadczące społeczeństwu usługi, często niemożliwe do pozyskania z innych źródeł [Jeżowski P 2009 s. 22.]

\section{USŁUGI EKOSYSTEMÓW - DEFINICJA POJĘCIA}

Usługi ekosystemów są definiowane, w najprostszym ujęciu, jako korzyści które czerpane są przez społeczeństwo z ekosystemów, rozumianych jako dynamiczne kompleksy złożone $\mathrm{z}$ roślin, zwierząt, mikroorganizmów i nieożywionych elementów środowiska pomiędzy którymi występują interakcje. [MEA, 2005, s. V] .

W literaturze przedmiotu istnieje wiele klasyfikacji usług ekologicznych. Najczęściej stosowane są klasyfikacje oparte na opracowaniu ONZ - Milenijna Ocena Ekosystemów [Millennium Ecosystem Assessment, MEA, 2005], w którym usługi te zostały przyporządkowane do czterech kategorii: usług podstawowych, zaopatrujących, regulacyjnych i kulturowych i zbliżona do niej klasyfikacja TEEB (,The Economics of Ecosystems and Biodiversity”).

Aby ujednolicić system klasyfikacji usług ekosystemowych, a jednocześnie ułatwić sprawozdawczość statystyczną Europejska Agencja Środowiska (European Environment Agency - EEA) opracowała Wspólną Międzynarodową Klasyfikację Usług Ekosystemów (Common International Classification of EcosystemServices - CICES), która ma obowiązwać 
we wszystkich krajach UE zapewniając tym samym porównywalność opracowań ${ }^{1}$.

Tabela. 1. Klasyfikacja usług ekosystemów wg. MEA

\section{Usługi ekosystemów}

\begin{tabular}{|c|c|c|c|}
\hline $\begin{array}{c}\text { Podstawowe } \\
\text { np. powstawanie gleb, } \\
\text { fotosynteza, obieg } \\
\text { składników } \\
\text { pokarmowych, } \\
\text { produkcja pierwotna, } \\
\text { obieg wód }\end{array}$ & $\begin{array}{c}\text { Zasobowe } \\
\text { np .pożywienie, } \\
\text { surowce materiałowe, } \\
\text { paliwa biomasowe, } \\
\text { woda pitna, pula } \\
\text { genowa, leki i } \\
\text { substancje naturalne, } \\
\text { elementy dekoracyjne } \\
\text { pochodzenia } \\
\text { naturalnego }\end{array}$ & $\begin{array}{c}\text { Regulacyjne } \\
\text { np. regulacja jakości } \\
\text { powietrza, klimatu, } \\
\text { stanu wód, kontrolę } \\
\text { erozji gleb, uzdatnianie } \\
\text { wody pitnej i } \\
\text { oczyszczanie ścieków, } \\
\text { ograniczenie ilości } \\
\text { zachorowań, } \\
\text { ograniczenie } \\
\text { wstẹpowania } \\
\text { szkodników, zapylanie, } \\
\text { łagodzenie naturalnych } \\
\text { zagrożeń }\end{array}$ & $\begin{array}{c}\text { Kulturowe } \\
\text { np. duchowe } \\
\text { wzbogacenie, rozwój } \\
\text { poznawczy, refleksje, } \\
\text { rekreacja } \\
\text { i przeżycia estetyczne }\end{array}$ \\
\hline
\end{tabular}

Źródło: Millennium Ecosystem Assessment

\section{WDRAŻANIE KONCEPCJI USŁUG EKOSYSTEMÓW}

Można stwierdzić, że w szerokim ujęciu koncepcja usług ekosystemów jest ramą do identyfikacji i ważenia ekonomiczno-społecznej wartości środowiska naturalnego [K. M. A. Chan i in, 2012.]

Podstawą wdrażania tej koncepcji jest zarówno określenie korzyści wynikających z prawidłowo funkcjonujących ekosystemów, jak również dostrzeżenie, że mogą one ulec zmniejszeniu w przypadku degradacji środowiska, a także wycenienie ich wartości ekonomicznej za pomocą dostępnych metod badawczych. [J. Kronenberg, 2016, s. 63-88]. Ewaluacja taka może przyczynić się do ograniczenia antropopresji na środowisko przyrodnicze ale również może być argumentem ,za” wprowadzaniu inwestycji i inicjatyw proekologicznych. Koncepcja ta jest coraz szerzej promowana w Unii Europejskiej, w szczególności w ramach unijnej Strategii na rzecz ochrony bioróżnorodności.

\footnotetext{
1 Więcej informacji na temat klasyfikacji CICES i porównania jej z TEEB i MAE na stronie http:// cices.eu/
} 
Rys 1. Zależności leżące u podstaw koncepcji usług ekoesystemów

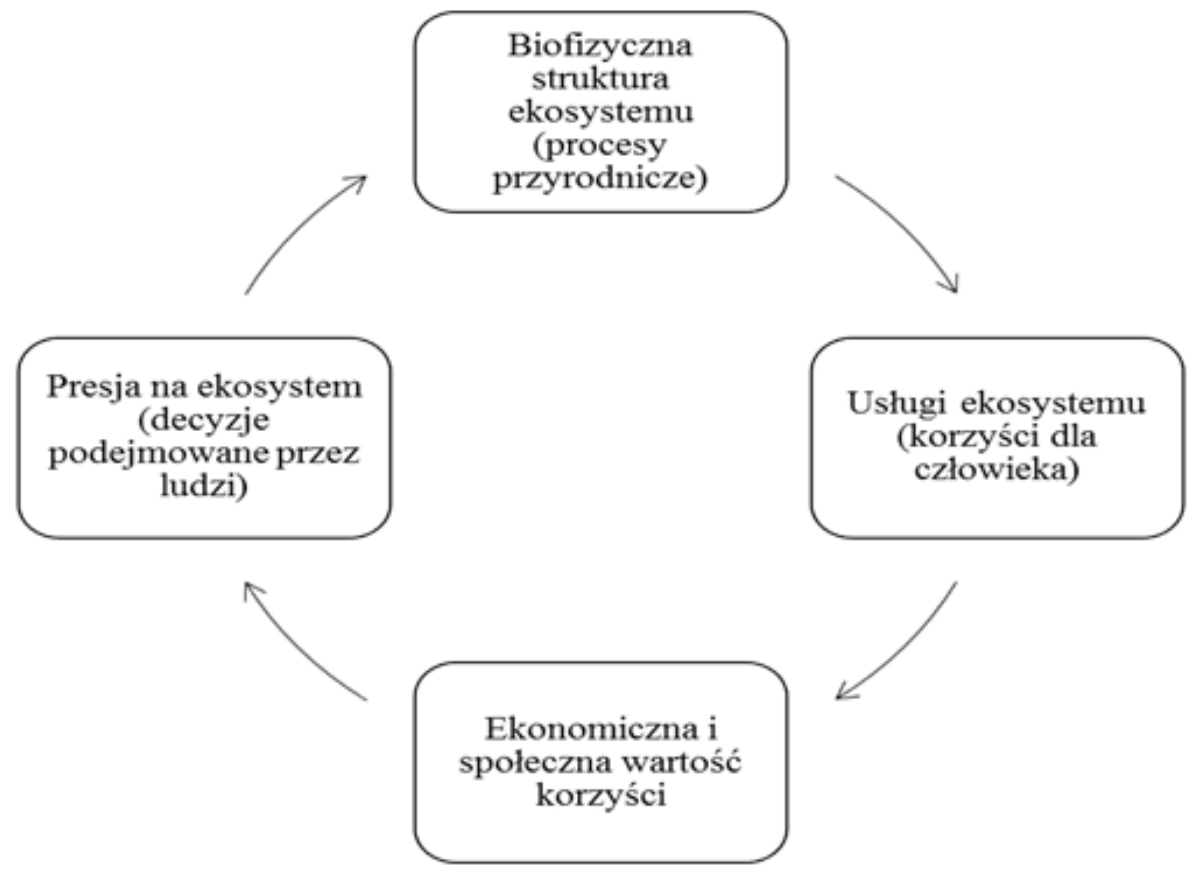

Źródło: J. Kronenberg, Usługi ekosystemów - nowe spojrzenie na wartość środowiska przyrodniczego, [w:] EkoMiasto\#Środowisko. Zrównoważony, inteligentny i partycypacyjny rozwój miasta, red. A. Rzeńca, Wydawnictwo Uniwersytetu Łódzkiego, Łódź 2016, s. 63-88.

Podstawą wdrażania tej koncepcji jest zarówno określenie korzyści wynikających z prawidłowo funkcjonujących ekosystemów, jak również dostrzeżenie, że mogą one ulec zmniejszeniu w przypadku degradacji środowiska, a także wycenienie ich wartości ekonomicznej za pomocą dostępnych metod badawczych. [J. Kronenberg, 2016, s. 63-88]. Ewaluacja taka może przyczynić się do ograniczenia antropopresji na środowisko przyrodnicze ale również może być argumentem ,za” wprowadzaniu inwestycji i inicjatyw proekologicznych. Koncepcja ta jest coraz szerzej promowana w Unii Europejskiej, w szczególności w ramach unijnej Strategii na rzecz ochrony bioróżnorodności.

Niemniej jednak należy podkreślić, że obiektywna ocena wartości zasobów przyrodniczych jest procesem niezwykle trudnym, ponieważ wiąże się ona z nadaniem miar pieniężnych zasobom często bezcennym lub podlegającym subiektywnej ocenie (w szczególności w zakresie walorów estetycznych, duchowych czy zdrowotnych).

W czasie podejmowania decyzji o przeprowadzeniu inwestycji mogącej wpłynąć na jakość usług ekosystemowych należy zatem podjąć działania mają- 
ce na celu określania ich wartości i ewentualnych korzyści/strat wynikających z danego przedsięwzięcia. Proces ten można przeprowadzić etapowo według schematu prezentowanego na diagramie poniżej.

Rys 2. Etapy szacowania wpływu inwestycji na wartość usług ekosystemowych

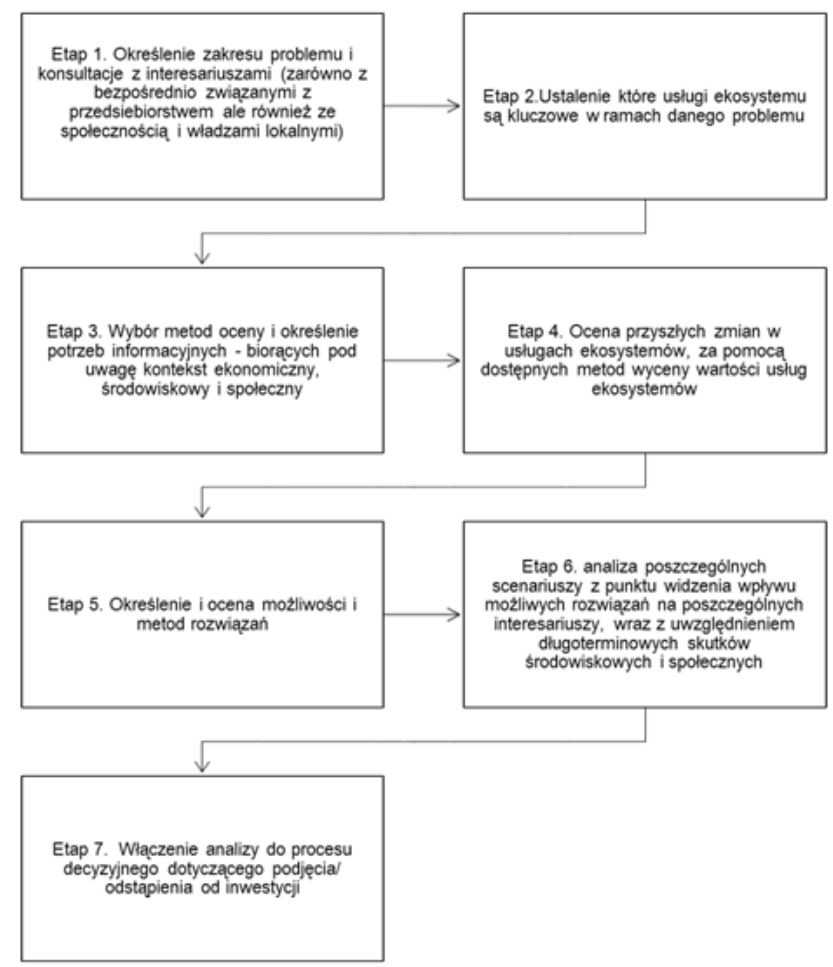

Źródło: opracowanie na podstawie: Daily G i in. 2000, Ekonomia ekosystemów i bioróżnorodności w polityce lokalnej i regionalnej 2011 i Chan K. M. A i in. 2012

Jednak jak podkreśla S. Czaja [2013, s. 273-290] przy wprowadzaniu kapitału naturalnego do rachunku ekonomicznego, trudności mogą pojawić się zarówno na etapie identyfikacji wszystkich czynników istotnych, jak również ich kwantyfikacji (w zakresie przedstawienia rozmiarów tych czynników w jednostkach naturalnych) i ich waloryzacji- sprowadzenia do wspólnej jednostki umożliwiającej ich agregację (np. jednostek pieniężnych). Problemem jest również to, ze rozważania dotyczące wpływu danej inwestycji na ekosystemy muszą uwzględniać nie tylko najbliższe otoczenie inwestycji ale czasem również systemy odleglejsze, niekiedy zaledwie pośrednio związane z danym przedsięwzięciem.

Aby ułatwić proces oceny wartości poszczególnych usług ekosystemów Konieczne jest opracowanie metod szacowania, które by dały możliwość bardziej 
obiektywnej ich waloryzacji, co pozwoli na bardziej racjonalne podejmowanie decyzji o potencjalnej inwestycji.

\section{METODY SZACOWANIA WARTOŚCI USŁUG EKOLOGICZNYCH}

Tak jak już wcześniej wspomniano obiektywna ocena wartości elementów kapitału naturalnego jest bardzo trudna o ile nie niemożliwa. J. Kronenberg podkreśla, że większość usług ekologicznych nie jest uwzględnianych w rachunkach i analizach ekonomicznych ponieważ nie są one przedmiotem obrotu na rynku. Niemniej jednak opracowanie metod obiektywnego wartościowania elementów ekosystemów pozwoliłoby na rozpatrywanie ich zużycia w kategoriach kosztów zewnętrznych, alternatywnych czy krańcowych, co mogłoby wpłynąć na analizę opłacalności inwestycji. Dla przykładu degradacja środowiska powodująca pozbawienie społeczeństwa możliwości funkcjonowania w zdrowym ekosystemie, może generować koszty zewnętrzne związane np. z leczeniem chorób z tego wynikających lub ponoszeniem dodatkowych wydatków związanych z pozyskiwaniem zasobów z innego źródła. Dlatego też wycena potencjalnych szkód, która wiązałaby się ze stworzeniem mechanizmów obciążających kosztowo inwestora (zgodnie z zasadą zanieczyszczający płaci) [J. Kronenberg, 2016, s. 63-88], mogłaby spowodować odstąpienie od danej inwestycji, lub też w przeciwnym przypadku gdy korzyści zewnętrzne przedsięwzięcia są znaczne - skłonić inwestora do podjęcia inicjatywy - ten aspekt szczególnie ważny jest w przypadku inwestycji publicznych.

Niestety wycena takich obciążeń jest tym trudniejsza, że często nie można jednoznacznie wskazać jaki jest koszt alternatywny danego użytkowania usług ekosystemów.

Do tej pory nie została stworzona sformalizowana metodologia wyceny usług ekosystemowych [J. Kronenberg, 2016, s. 63-88]. W literaturze przedmiotu można spotkać wiele prób wskazania właściwych metod szacowania wartości takich usług. Generalnie można je podzielić na metody rynkowe i nierynkowe (inaczej pieniężne i niepieniężne). Do metod nierynkowych oceny wartości elementów środowiskowych należą m.in. obserwacja uczestnicząca, storytelling, mapowanie społeczne czy analiza dokumentów statystycznych [E. Kelemen i in. 2016]. Metody pieniężne polegają na odniesieniu wartości ekosystemów, do cen rynkowych i to właśnie ta grupa w ocenie autorki może dostarczyć argumentów mających wpływ na ocenę opłacalności inwestycji ponieważ oceny te są o mniej subiektywne niż te oparte na metodach nierynkowych.

Wśród metod pieniężnych łączonych z usługami ekosystemów wymienia się m. in. metodę kosztu podróży, metody hedoniczne, metodę kapitału ludzkiego czy metodę deklarowanych preferencji. 
Tab. 2. Przykładowe metody waloryzacji usług ekosystemów.

\begin{tabular}{|c|c|c|c|}
\hline Metoda & Działania & Podstawa waloryzacji & Ograniczenia \\
\hline $\begin{array}{l}\text { Metoda kosztów } \\
\text { podróży }\end{array}$ & $\begin{array}{l}\text { Estymacja wartości } \\
\text { dóbr nierynkowych na } \\
\text { postawie danych o wy- } \\
\text { datkach budżetowych i } \\
\text { zachowaniach osób }\end{array}$ & $\begin{array}{l}\text { Wartość kosztu podró- } \\
\text { ży do miejsc rekreacji i } \\
\text { czasu utożsamia się z } \\
\text { wartością ekonomiczną } \\
\text { aktywów naturalnych }\end{array}$ & $\begin{array}{l}\text { Dostępność danych, } \\
\text { zwłaszcza z zakresu } \\
\text { popytu na wypoczynek } \\
\text { w określonych regio- } \\
\text { nach. }\end{array}$ \\
\hline $\begin{array}{l}\text { Metoda cen he- } \\
\text { donicznych }\end{array}$ & $\begin{array}{l}\text { Szacowanie nierynko- } \\
\text { wych elementów śro- } \\
\text { dowiska na podstawie } \\
\text { dóbr zastępczych (np. } \\
\text { Nieruchomości albo } \\
\text { pracy) }\end{array}$ & $\begin{array}{l}\text { Wpływ czynników eko- } \\
\text { logicznych na poziom } \\
\text { cen nieruchomości czy } \\
\text { wysokość płac jest mia- } \\
\text { rą wyceny środowiska }\end{array}$ & $\begin{array}{l}\text { Można stosować tylko, } \\
\text { gdy istnieją rynki po- } \\
\text { równywalne lub rów- } \\
\text { noległe }\end{array}$ \\
\hline $\begin{array}{l}\text { Metoda kapitału } \\
\text { ludzkiego }\end{array}$ & $\begin{array}{l}\text { Identyfikacja cech } \\
\text { środowiska będacych } \\
\text { przyczyna chorób, } \\
\text { oszacowaniem liczby } \\
\text { zagrożonych ludzi i } \\
\text { obliczaniu prawdopo- } \\
\text { dobnych strat w czasie } \\
\text { pracy i wydatków na } \\
\text { leczenie }\end{array}$ & $\begin{array}{l}\text { Przedmiotem sa straty } \\
\text { w zarobkach uwarun- } \\
\text { kowane czynnikami } \\
\text { środowiskowymi oraz } \\
\text { koszty leczenia i opieki } \\
\text { społecznej }\end{array}$ & $\begin{array}{l}\text { Ograniczana jest } \\
\text { problemami natury } \\
\text { informacyjnej, doty- } \\
\text { czącymi zwiazków po- } \\
\text { między środowiskiem } \\
\text { i zdrowiem ludzkim. } \\
\text { Nie ma także zasto- } \\
\text { sowania dla ludno- } \\
\text { ści nieprodukcyjnej } \\
\text { i będącej pod koniec } \\
\text { wieku produkcyjnego }\end{array}$ \\
\hline $\begin{array}{ll}\text { Metoda dekla- } & \text { rowanych prefe- } \\
\text { rowai } & \\
\text { rencji }\end{array}$ & $\begin{array}{l}\text { Gromadzenie opinii lu- } \\
\text { dzi na temat ich zapo- } \\
\text { trzebowania na czyste } \\
\text { środowisko przyrodni- } \\
\text { cze }\end{array}$ & $\begin{array}{l}\text { Badane są gotowość } \\
\text { płacenia za pewne ko- } \\
\text { rzyści środowiskowe, } \\
\text { lub gotowość akcepta- } \\
\text { cji rekompensaty pie- } \\
\text { niężnej strat w jakości } \\
\text { środowiska }\end{array}$ & $\begin{array}{l}\text { Problem prawdziwości } \\
\text { odpowiedzi czy upraw- } \\
\text { nienia w przenoszeniu } \\
\text { wniosków z badanej } \\
\text { próbki na cała popula- } \\
\text { cję }\end{array}$ \\
\hline
\end{tabular}

Źródło: Opracowanie na podstawie: Becla A., 2013, s. 292- 301.

Wprawdzie wątpliwości co do zasadności i wykonywalności waloryzacji przyrodniczej, jak i metod do niej stosowanych są obecnie tematem dyskusji naukowej, mimo tego koncepcja szacowania strat w obrębie usług środowiskowych coraz częściej znajduje zastosowanie w procesie decyzyjnym warunkującym przeprowadzenie inwestycji.

\section{PODSUMOWANIE}

Obecnie coraz częściej podkreślany jest negatywny wpływ działalności człowieka na środowisko naturalne. Zainteresowanie problemami środowisko- 
wymi znajduje również odzwierciedlenie zarówno w dokumentach rządowych jak i strategiach działania organizacji gospodarczych. Coraz częściej w procesach decyzyjnych podejmowany jest temat usług ekosystemów, nadal jednak nie opracowano obiektywnych metod szacowania ich wartości, co utrudnia uwzględnianie ich w rachunkach i analizach ekonomicznych. Niemniej jednak dzięki choćby szacunkowemu określeniu bilansu strat i zysków związanych $\mathrm{z}$ określonym wpływem na środowisko $\mathrm{w}$ danym procesie inwestycyjnym można, w opinii autorki, dostarczyć dodatkowych argumentów „za” bądź „przeciw” w ocenie szacowania opłacalności inwestycji.

\section{LITERATURA}

Becla A., (2013), Wybrane informacyjne wyzwania identyfikacji i wyceny elementów kapitatu naturalnego dla rachunku ekonomicznego. [w]: Prace naukowe Uniwersytetu Ekonomicznego we Wrocławiu nr 317.

Chain K. M. A., Guerry A. D., Balvanera P., Klain S., Satterfield T. , Basurto X., Bostrom A., Chuenpagdee R., Gould R., Halpern B. S., Hannahs N., Levine J., Norton B., Ruckelshaus M., Russell R., Tam J., Woodside U., (2012), Where are Cultural and Social in Ecosystem Services? A Framework for Constructive Engagement, BioScience 62 (8).

Czaja S., (2013), Wybrane problemy metodyczno-metodologiczne wyceny elementów kapitalu naturalnego [W]: Prace naukowe Uniwersytetu Ekonomicznego we Wrocławiu nr 317.

Daily G., Söderqvis T., Aniya S, Arrow K., Dasgupta P., Ehrlich P.R., Folke C., Jansson A, Jansson B., Kautsky N., Levin S., Lub.chenco J, Mäler K., Simpson D., Starrett D., Tilman D., Walker B., (2000), The Value of Nature and the Nature of Value [w:] Vol. 289. nr. 5478.

Fundacja Sendzimira Ekonomia ekosystemów i bioróżnorodności w polityce lokalnej i regionalnej. PORADNIK TEEB DLA MIAST: ustugi ekosystemów w gospodarce miejskiej., Kraków 2011. ISBN 978-83-62168-02-6.

Górnicki K., (2012), Kapitat naturalny, jako kategoria socjologiczna.[W]: Pogranicze. Studia Społeczne. Tom XX.

Jeżowski P., (2009), Podstawy regulacji środowiska i zdrowia [w:] Jeżowski p. (red.) Metody szacowania korzyści i strat w dziedzinie ochrony środowiska i zdrowia, SGH, Warszawa.

Kelemen, E., García-Llorente, M. Pataki, G. Martín-López B., Gómez-Baggethun E. (2016): Non-monetary techniques for the valuation of ecosystem service. [w:]: Potschin, M. and K. Jax (red.): OpenNESS Ecosystem Services Reference Book. EC FP7 Grant Agreement No. 308428. Dostępne na: www.opennessproject.eu/library/reference-book [15.02.2017]

Kronenberg J., (2016), Ustugi ekosystemów - nowe spojrzenie na wartość środowiska przyrodniczego, [w:] EkoMiasto\#Środowisko. Zrównoważony, inteligentny i partycypacyjny rozwój miasta, red. A. Rzeńca, Wydawnictwo Uniwersytetu Łódzkiego, Łódź.

MEA (2005), Millennium Ecosystem Assessment.

Poskrobko B., (2007), Zarządzanie środowiskiem, PWE, Warszawa.

\section{ENVIRONMENTAL SERVICES AS AN ELEMENT OF ASSESSMENT OF PROFITABILITY OF INVESTMENTS}

Abstract: The subject of the article is the essence of the concept of ecosystem services valuation. The author attempts to characterize these services, as well as indicates the importance of assess- 
ment of their value in the investment decision-making process, particularly in terms of their profitability Article also presents examples of methods for assessing the value of ecosystem services and indicates the difficulties that accompany this process

Keywords: ecosystem services, assessment of the value of ecosystem services, environmental costs 
